\title{
ЗАТЕВАХИН Игорь Иванович (к 80-летию со дня рождения)
}

20 февраля 2016 года исполняется 80 лет со дня рождения Презедента Российского общества хирургов, заведующего, кафедрой факультетской хирургии, урологии педиатрического факультета РНИМУ им. Н.И. Пирогова, доктора медицинских наук, профессора, академика РАН, Заслуженного деятеля науки РФ Игоря Ивановича Затевахина.

Игорь Иванович родился в 1936 году в Москве в семье военнослужащего. С юных лет в спорте, в 13 лет он стал чемпионом Москвы по плаванию, а в 19 лет мастером спорта СССР по водному поло.

Медицинское образование и последующая профессиональная деятельность И.И.Затевахина самым тесным образом связана со 2-ым МОЛГМИ им. Н.И.Пирогова. После окончания в 1960

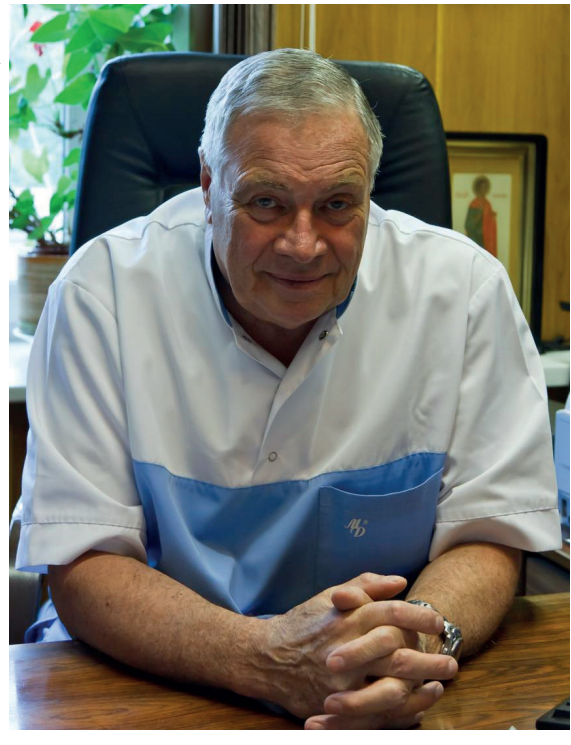

шие настольными книгами для многих поколений советских и российских хирургов.

Начиная с 1980 года, параллельно с разработкой проблемы острой артериальной непроходимости, в научных исследованиях И.И.Затевахина центральное место занимает изучение вопросов, связанных с острой хирургической патологией органов брюшной полости.

И.И.Затевахин и сотрудники руководимой им клиники внесли большой вклад в решение проблемы хирургического лечения патологии желчных путей и заболеваний поджелудочной железы. Комплексная оценка ближайших и отдаленных результатов лечения желчекаменной болезни и ее осложнений в целом позволила И.И.Затевахину по-новому оценить показания к выбору году лечебного факультета он начинает работать ординатором 1-ой Городской клинической больницы, в клинике руководимой академиком А.Н.Бакулевым. С 1965 года Игорь Иванович перешел на работу ассистентом кафедры факультетской хирургии им. С.И.Спасокукоцкого, где последовательно занимал должности ассистента, доцента, заведующего лабораторией, профессора кафедры факультетской хирургии. В 1982 году избран заведующим кафедрой хирургических болезней педиатрического факультета 2-го МОЛГМИ им. Н.И.Пирогова.

В 1967 году И.И.Затевахин успешно защищает кандидатскую диссертацию на тему: «Эмболии магистральных артерии конечностей», выполненную под руководством профессора В.С.Савельева.

В 1975 году им защищена докторская диссертация на тему: «Хирургия острой эмбологенной артериальной непроходимости».

И.И.Затевахин - высококвалифицированный, поливалентный хирург, ученый, нацеленный на разработку и внедрение новых способов диагностики и лечения широкого круга хирургических заболеваний органов брюшной полости, аорты и магистральных сосудов.

Под руководством И.И.Затевахина детально изучены проблемы этилогии эмболий аорты и артерий конечностей, патогенез синдрома острой ишемии и постишемических нарушений, вопросы диагностической тактики при острых артериальных окклюзиях и разработки новых методик оперативного лечения острых окклюзий аорты и магистральных артерий конечностей.

Логическим завершением этого этапа научной деятельности И.И.Затевахина явилась публикация монографий "Эмболия бифуркации аорты и магистральных артерий конечностей" (1970) и "Острая непроходимость бифуркации аорты и магистральных артерий конечностей" (1986), ставметода лечения этой патологии, особенно у лиц с высокой степенью риска и обобщить результаты исследований в монографии "Острый холецистопанкреатит» (1986). Современным методам диагностики различных форм деструктивного панкреатита и разработанной принципиально новой хирургической тактике лечения панкреонекроза с изучением ближайших и отдаленных результатов посвящена монография «Панкреонекроз» изданная в 2007 году.

Существенным вкладом И.И.Затевахина в современную хирургическую гастроэнтерологию послужили результаты применения эндоскопических и эндоваскулярных методов гемостаза, а также разработка и внедрение в клиническую практику системы балльной оценки угрозы рецидива кровотечения у больных с язвенной болезнью желудка и 12-ой кишки. В 1996 году была издана монография "Хирургическая тактика при язвенных гастродуоденальных кровотечениях" и в 2002 году монография «Новые технологии в лечении язвенных гастродуоденальных кровотечений».

И.И.Затевахин и руководимая им школа хирургов внесли большой вклад в изучение проблемы хирургического лечения хронических тромбооблитерирующих заболеваний аорты и артерий нижних конечностей, им предложены принципиально новые виды микрохирургических вмешательств при акральных формах поражения артерий, предложен принципиально новый подход к выполнению ранних повторных, так называемых, "превентивных" операций, позволяющих в большинстве наблюдений предотвратить развитие ишемии в условиях формирующейся реокклюзии. Результаты проведенных исследований были положены в основу изданной в 1993 году монографии "Реконструктивная хирургия поздней реокклюзий аорты и периферических артерий".

Большой вклад профессор И.И.Затевахин и сотрудиники руководимой им клиники внесли в разработку и внедрение в практику новых, неинвазивных методов диагно- 
стики поражения сосудов, ультразвукового допплеровского исследования кровотока, ультразвуковому сканирования. В 1999 году была издана монография «Тредмил в диагностике и лечении хронической артериальной недостаточности»

Одна из основных проблем современной хирургии - проблема хирургической инфекции в сосудистой хирургии - получила новое развитие в работах И.И.Затевахина и сотрудников его клиники. В 1998 году была издана первая в нашей стране монография "Инфекция в сосудистой хирургии", в которой были отражены вопросы диагностики, лечения и профилактики послеоперационных осложнений у больных с облитерирующими заболеваниями брюшной аорты и ее ветвей, сопровождающиеся различными проявлениями раневой инфекции и сепсисом.

Результаты научных исследований И.И.Затевахина по проблеме облитерирующего тромбангиита, вопросов этилогии, патогенеза и лечения этого заболевания, были в 2002 году обобщены в монографии «Облитерирующий тромбангиит».

И.И.Затевахин является основоположником нового направления в сосудистой хирургии - гибридных операций. Разработанные методики операций были впервые представлены в 2004 году в руководстве для врачей «Баллонная ангиопластика при ишемии нижних конечностей».

В 2006 году за выдающийся вклад в развитие отечественной сосудистой хирургии И.И.Затевахин награжден Золотой медалью академика А.Н.Бакулева.

Многогранность научных интересов И.И.Затевахина позволила ему внести существенный вклад в развитие отечественной флебологии и онкологии, разработать показания и методику исполнения различных комбинированных хирургических вмешательств, в частности, при кистах поджелудочной железы с арозией верхне-брыжеечной артерии, при сочетании аневризм дистального отдела аорты с опухолями толстой кишки, осложненных аневризм абдоминаль- ной аорты и многих других. В 2010 году опубликована монография «Осложненные аневризмы абдоминальной аорты».

В последние годы под руководством И.И.Затевахина разрабатывается проблема лечения портальной гипертензий и кровотечений из варикозно расширенных вен пищевода и желудка при циррозах печени. В клинике накоплен самый большой материал в России по трансъюгулярному портосистемному шунтированию (TIPS)и лигированию варикозно расширенных вен с изучением ближайших и отдаленных результатов. За цикл работ по портальной гипертензии И.И.Затевахин был дважды, в 1996 и 2004 годах, удостоен Премии г. Москвы в области здравоохранения и медицины, а в 2009 - Премии Правительства РФ в области науки и техники.

Профессор И.И.Затевахин является автором более 500 научных работ, в том числе 12 монографий, 35 глав в руководствах, книгах и учебниках.

Под руководством и при научной консультации профессора И.И.Затевахина защищены 18 докторских и 64 кандидатских диссертации.

Его многочисленные ученики заведуют отделениями и кафедрами в различных городах России и СНГ.

Профессор И.И.Затевахин ведет большую общественную работу, являясь Президентом Российского общества хирургов, Вице-президентом Общества хирургов России, действительным членом Европейской ассоциации сосудистых хирургов, членом редколлегии различных хирургических журналов.

Воронежский государственный медицинский университет им. Н.Н. Бурденко, редколлегия журнала «Вестник экспериментальной и клинической хирургии» $u$ Воронежское отделение Российского общества хирургов поздравляют Игоря Ивановича с Юбилеем и желают ему многих лет такой же яркой и насыщенной жизни, творческих успехов, здоровья и благополучия. 